\title{
Transport Sediment Analysis Using Bed-Load: Case Study Bilibili Reservoir
}

\author{
Melly Lukman ${ }^{1}$, Benyamin Tanan ${ }^{1}$, Zubair Saing ${ }^{2, *}$ \\ ${ }^{1}$ Department of Civil Engineering, Universitas Kristen Indonesia Paulus (UKIP), Indonesia \\ ${ }^{2}$ Department of Civil Engineering, Universitas Muhammadiyah Maluku Utara (UMMU), Indonesia
}

Received May 22, 2020; Revised July 2, 2020; Accepted July 29, 2020

Copyright $\odot 2020$ by authors, all rights reserved. Authors agree that this article remains permanently open access under the terms of the Creative Commons Attribution License 4.0 International License

\begin{abstract}
This study conducted to analyze transport sediment using bed-load in the Bilibili reservoir case, South Sulawesi, Indonesia. The laboratory test has done to determine the basic characteristics of samples consisting of sediment concentration tests and specific gravity tests. Furthermore, the data analysis using Van Rijn formulation to calculate bed sediment discharge $(\mathrm{Qb})$ and flow rate $(\mathrm{Q})$, and analysis result found the relationship between bed sediment discharge and flow rate expressed in equation $\mathrm{y}=$ $12.314 \mathrm{x} 1.4292$ where $\mathrm{y}=\mathrm{x} . \mathrm{Qb}=\mathrm{Q}$. Therefore, the existing sediment transport amount of the Bilibili reservoir for 2014 to 2018 is 1.102 million tons, 1.426 million tons, 0.737 million tons, 1.277 million tons, and 0.895 million tons, respectively. Besides, total sediment is 216,9261.2 tons/year equivalent to $6,142 \mathrm{~m}^{3} /$ year, and the percentage of bed sediment transport to total sediment is $70.5 \%$. The analysis results also indicate an increase in bed sediment discharge due to an increase in river water discharge. The condition explains that increasing the flow rate causes the amount of transported sediment to increase.
\end{abstract}

Keywords Flow Rate, Bed Transport Sediment, Bed-Load, Water Discharge

\section{Introduction}

The reservoir is water management to collect water flows in a watershed system network built by making a dam in the downstream. In addition, to collect transported water and soil erosion in the river upstream, the reservoir also serves to prevent flooding and erosion in the downstream [1,2].

Sediment potential due to massive landslides will flow downstream if the intensity of the rain is high and that it is prone to debris flow with high concentrations [3-5]. The condition caused by that Jeneberang river continues to drain sediment during floods and settles along the river channel to the Bilibili reservoir [6]. As a result of a considerable volume of Bawakaraeng mountain caldera collapse, approximately 201 million $\mathrm{m}^{3}$ sediment flows along the Jeneberang River and into various existing water structures, such as sabo dam increased rapidly [6]. The landslide eroded and damaged the existing sabo dam and sand pocket and would increase sedimentation in the Bili-Bili Reservoir, thereby causing the reservoir siltation, which will ultimately reduce the operational life of reservoir and threaten reservoir functions sustainability.

The study on sediment transport, especially bed-load measurements, has been carried out and reported well as described below. The use of geophones to measure sediment bed-load found that there is a linear relationship between the amount of impulse and charge mass passing through the sensor. This finding is used to calibrate the geophone signal to determine the bed-load transport velocity [7-9]. Measurement of bed-load transport speed using bathymetry data with sequential time is as accurate as using measurements using amplitude and speed. However, it is necessary to consider waveform deformation due to unstable flow properties and three-dimensional bathymetry surfaces [10].

Furthermore, the study to develop a bed-load transport concept in a number flow and sediment conditions, especially the coastal marine environment, has found the new formulation of bed-load transport. They were using 150 laboratory experiments results and more than 75 measurements of bed-load transportation conducted to validate and limitation of the bed-load transport model [11]. The prediction of bed roughness and bed-load transport in steady river flow is extended to coastal flow, applying an interweave approach and propose simplified bed-load transport formulas [12].

Meanwhile, bed-load transport analysis is fundamental in sediment potential monitoring in a reservoir. Besides, to overcome the problem of landslides, improvements, and 
additions, the sediment control structure such as the Sabo dam, check dam, consolidation dam, and sandbags carried out. Therefore, the study conducted to analyze the transport of sediments entering the Bilibili Reservoir using bed-load analysis.

\section{Literature Review}

\subsection{Watershed Management}

The watershed concept is the basis of all hydrological planning. Since large watersheds are composed of smaller watersheds, and these smaller watersheds are also composed of smaller watersheds. Generally, a watershed defined as an area bounded by natural boundaries, such as ridges or mountains, or artificial boundaries as roads or embankments where rainfall falling in the area contributes to the control points (outlets). The watershed is an area bounded by topographic separators that receive rainwater, store and drain into rivers, and so on into lakes or the sea $[13,14]$.

Therefore, watershed management efforts are a form of regional development that places the watershed as a management unit, trying to use natural resources in a watershed rationally to achieve optimum production goals in unlimited time so that the distribution of flow evenly distributed throughout the year $[15,16]$ - rivers functions as collecting rainfall in the watershed and flow it to the sea. The function of the river also for agriculture, flood control, freshwater, and water power $[17,18]$.

Watershed management is a regional development form that places the watershed as its development unit. Three main aspects are always a concern in watershed management: water amount (water yield), supply time (water regime), and sediment. A watershed can see as a hydrological system influenced by the precipitation variable as input into the system. Besides, the watershed has a specific character and is closely related to its primary elements, such as soil type, topography, geology, geomorphology, vegetation, and land use. Watershed characteristics in catching rainfall effect evapotranspiration rate, infiltration, percolation, surface flow, groundwater content, and river flow.

In river channel maintenance at downstream, generally, sedimentation occurs. As a result of deposition, the wet cross-sectional area reduced. If sedimentation occurs in a part of a river, then the dredging part of the river needs to be carried out dredging so that the drainage capacity does not decrease $[19,20]$. The quite prominent area of riverbank needs to be compressed so that no crossing occurs during a flood that can threaten the stability of both the embankment and riverbank.

\subsection{River Flow Discharge}

River flow is the volume of water that flows through the river's cross-section at a particular area with the velocity that affects each other, especially rainfall and physical properties [21,22]. River flow data is the most important information for water resources management, while flow rate is water flow (in water volume) that passes through a cross-section in time unit. River discharge is obtained after measuring water velocity using a device such as a current meter or buoy to find out the river flow velocity data. The factors that influence discharge and characteristics are grouped into [23]; 1) factors influence the total runoff volume include climate factors, precipitation, and evaporation; 2) Watershed factors consist of watershed size, topography, soil type, vegetation, drainage water (river sequence) and drainage runoff; and 3) human factors include agricultural techniques and urbanization.

The river discharge needed in studies to determine the flow volume caused by river structures implementation by humans, then further, because the discharge amount is equal to the wet cross-section area multiplied by the current velocity, then its measurement directed against these two factors.

\subsection{Sediment}

Sediment is the result of erosion, either in surface erosion, ditch erosion, or soil erosion. Sediment generally settles at foothills, flooded areas, waterways, rivers, and reservoirs. The sediment yield is a sediment amount derived from erosion in the catchment area measured at a certain period and place. The sediment yields usually obtained from dissolved sediment measurements in rivers (suspended sediment). In other words, sediments are fragments, minerals, or organic materials that transferred from various sources and deposited by air, wind, ice, or water, and also included deposited from material floating in the water or the chemical solutions forms [24].

Each river carries several suspended sediments and moves solid materials along the riverbed as bed loads. Because the specific gravity of soil material is approximately $2.65 \mathrm{~g} / \mathrm{cc}$, floating sediment particles tend to settle at groove bottom. However, the upward current in the turbulent flow prevents gravitational precipitation. If the water-containing sediment reaches a reservoir, the velocity and turbulence will significantly reduce. Floating sediment loads in rivers are cured by taking water samples, filtering them to separate the sediment, drying it, and weighing the filtered material - sediment loads expressed in parts per million (ppm). Sediments aerated in a river valley in the rainfall event can be deposited in the river channel and stay there until the next rainfall pushes it downstream. Certain parts of the river basin may be more sensitive to erosion than other parts so that a higher sediment load expected if rainfall concentrated in such areas.

The sedimentation process consists of process erosion, transportation, deposition, and compaction. The process is very complex, starting from the rainfall, which produces 
kinetic energy, which is the initial erosion process. The fine-grained soil will roll along with the flow, and some left above while the other part enters the flow channel into a sediment transport. The soil ability erodes not only on particle sizes but also on the physical properties of organic and non-organic materials bound together with the particles. If the eroded soil particles from the bottom and cliff are eroded, the sediment will move continuously into the sediment transport. Sediment transport can be measured at an estimated water post location so that sediment yield can calculate from a watershed [25-27].

The riverbed is composed of sediment transport material carried by river flow that can transport back in high flow velocity. The huge sediment transport volume depends on flow velocity change, seasons change, and velocity change influenced by human activities. Sediment load is the total sediment transported by river flow at a particular measurement location expressed in weight per time (tons/day or $\mathrm{kg} / \mathrm{sec}$ ) or volume units $\left(\mathrm{m}^{3} /\right.$ day).

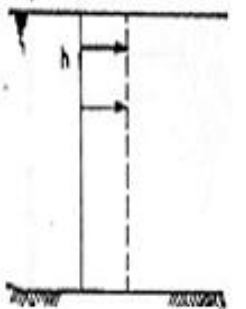

Fine Load

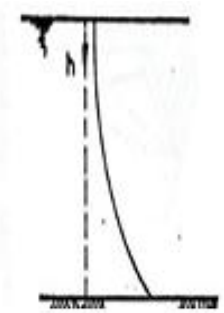

Suspended-Load

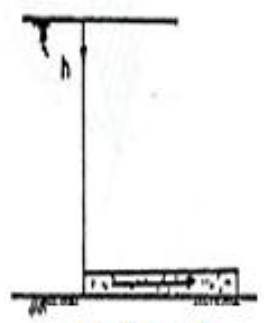

Bed-load
Figure 1. Sediment classification

Based on the transportation method, sediment loads classified into two: bed-load sediment and suspended load sediment. Bed-load is part of a sediment load that moves along the riverbed by rolling, jumping, or shifting. In contrast, the suspended load is part of the sediment load that moves floated in the flow and interacts very little with the river bed because it always pushed upward by flow turbulence. The bed-load is rougher than the suspended load. Moreover, based on sediment particle size, the sediment load divided into two: bed-material load and fine-material load. The bed materials are sediment at the riverbed, have a coarse particle size, and tend to settle on flow conditions. Whereas fine material load is a sediment load with fine size, not from a riverbed, and tends to settle [28]. Sediment load types, as represented in Fig. 1 [29,30].

\section{Methodology of Research}

\subsection{Sediment Sampling}

The present study was conducted in Bilibili watershed Jeneberang river South Sulawesi Province, Indonesia, and the sampling location as presented in Fig. 2. Sediment sampling conducted shortly after discharge measurement in a river. The sampling is useful to determine bed sediment concentration and bed sediment volume per unit time transported during measurement. The measurement location must qualify as a bed sediment concentration location, including 1) The flow is not abundant, the straight river channel along more than $3 \mathrm{x}$ the width of the flow when flooded and easily reached. 2) Free from backflow, flowing. 3) Sediment concentrations mixed at the measurement cross-section width. 4) Flow without turbulence so that the sediment is mixed though turbulence is not high. When high turbulence, it is not appropriate as a location for discharge measurements. 5) There is a cable car or other measurement during floods. 6) The shape of the river cross-section is regular, not rocky, has no floodplains, and there is no narrowing of the channel or a meaningful widening of the channel. 


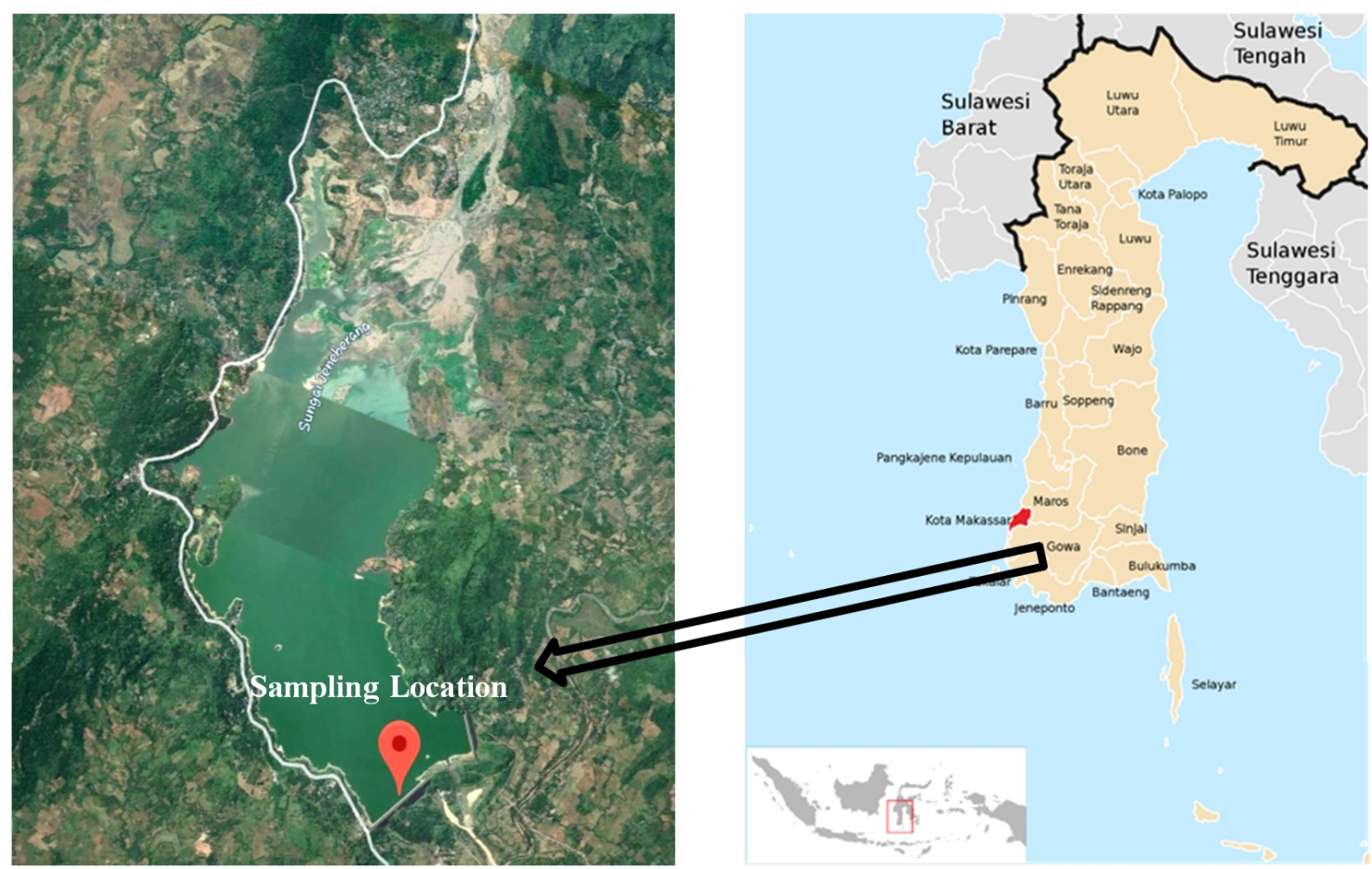

Figure 2. Sampling location of Bilibili watershed sediments
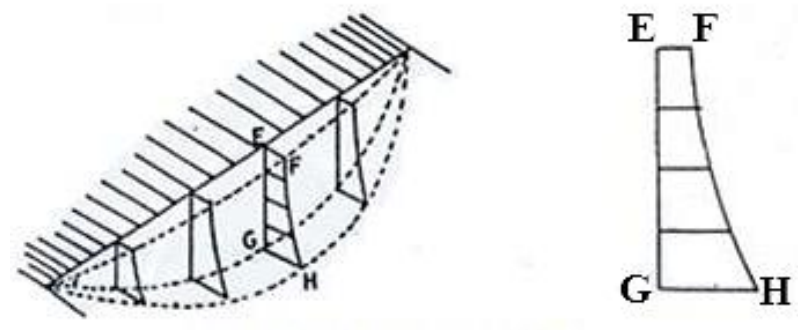

Sediment Concentration

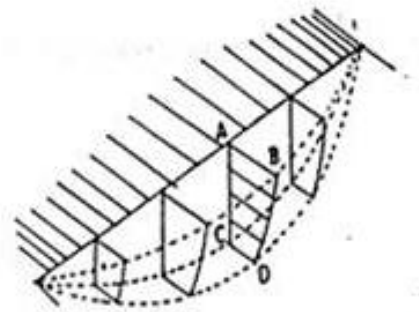

Flow Velocity

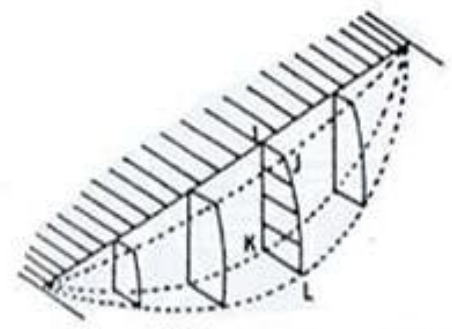

Sediment Volume
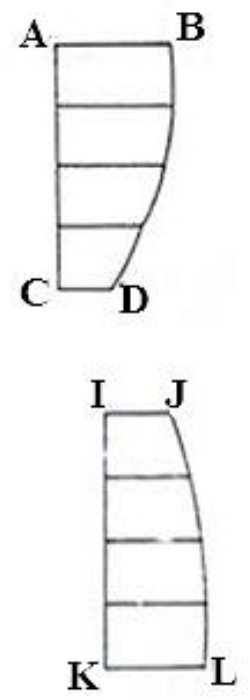

Figure 3. Sketch of vertical flow curve, sediment concentration and sediment volume
One of the two methods of measurement of sediment concentration can be point integration and depth integration. The point Integration method is the point of sampling to obtain distribution data of sediment concentration suspense versus depth. The integration method is required when the desired depth analysis of hydrologic concerning sediment suspension watershed. In Indonesia generally uses depth integration methods. River cross-section divided into several vertical paths (vertical distance from the riverbed to water-wet surface cross-section) as seen in Fig. 3.

Furthermore, the sample from a sampling site conducts a laboratory test to determine bed sediment concentration and dry specific gravity. Bed sediment samples analyzed in the laboratory directly, after being deposited for 1-2 days, the concentration of sediment determined by weighing dried sediment content and dividing by sediment volume into units: $\mathrm{mg} / \mathrm{l}$, or $\mathrm{g} / \mathrm{l}$, or $\mathrm{g} / \mathrm{m}^{3}$, or $\mathrm{kg} / \mathrm{m}^{3}$, or parts per million, or stated in $\%$. There are two methods typically used to determine sediment concentration: the precipitation method and filtration method. Precipitation method is a sediment concentration test using gravimetry and is a simple method-the provisions of this test based on Indonesian Standard (SNI 03-3961-1995).

The test analysis conduct starts from depositing the sediment level then drying in an oven. While filtering method conducts if sediment particles will not be analyzed. Specific gravity is a ratio between sediment weight with distilled water at a volume and the same temperature. The determination of specific gravity performed by measuring the weight and volume of sediment using the Picnometer tool based on SNI 03-4 145-1996. 


\subsection{Data Analysis}

Bed-load transport sediment accurately analyzes with two dimensionless parameters [31]: particle parameter $(\mathrm{P})$ and critical mobility parameter (C). Particle parameter determined using Equation 1.

$$
D_{*}=D_{50}\left[\frac{(s-1) g}{v^{2}}\right]^{1 / 3}
$$

Where: $\mathrm{D}_{50}=$ average particle size, $\mathrm{S}=$ particle density $\left(\rho_{\mathrm{s}} / \rho\right), \rho s=$ particle density, $\rho=$ water density, $\mathrm{g}=$ acceleration due to gravity, $v=$ kinematic viscosity $(\mu / \rho)$, and $\mu=$ dynamic viscosity.

Meanwhile, critical mobility parameter determined using Equation 2.

$$
\theta_{c r}=\frac{\left(u_{*, c r}\right)^{2}}{(s-1) g D_{50}} \text { or } \mathrm{u}_{*, \mathrm{cr}}=\left[\theta_{\mathrm{cr}}(\mathrm{s}-1) \mathrm{gD}_{50}\right]^{0.5}
$$

Where $\theta_{\text {cr }}$ is obtained with calculated from the equation:

$$
\begin{aligned}
& \theta_{\mathrm{cr}}=0.24\left(\mathrm{D}_{*}\right)^{-1} \quad \text { If } \mathrm{D}_{*} \leq 4 \\
& \theta_{\mathrm{cr}}=0.14\left(\mathrm{D}_{*}\right)^{-0.64} \text { If } 4<\mathrm{D}_{*} \leq 10 \\
& \theta_{\mathrm{cr}}=0.04(\mathrm{D} *)^{-0.10} \text { If } 10<\mathrm{D}_{*} \leq 20 \\
& \theta_{\mathrm{cr}}=0.01\left(\mathrm{D}_{*}\right)^{0.29} \text { If } 20<\mathrm{D}_{*} \leq 150 \\
& \theta_{\mathrm{cr}}=0.055 \quad \text { If } \mathrm{D} *>150
\end{aligned}
$$

Chezy Coefisien:

$$
C^{\prime}=18 \log \left(\frac{12 R_{b}}{3 D_{90}}\right)
$$

For wide channel the assumption: $\mathrm{R}_{\mathrm{b}}=\mathrm{d}$ (depth of flow), Grain-shear velocity:

$$
u_{*}^{\prime}=\frac{g^{0.5} \bar{u}}{C^{\prime}}
$$

\section{Transport stage parameter:}

$$
T=\frac{\left(u_{*}^{\prime}\right)^{2}-\left(u_{*, c r}\right)^{2}}{\left(u_{*, c r}\right)^{2}}
$$

Sediment discharge per meter wide of river:

$$
\mathrm{q}_{\mathrm{b}}=0.053 \frac{\mathrm{T}^{2.1}}{\mathrm{D}_{*}^{0.3}}[(\mathrm{~s}-1) \mathrm{g}]^{0.5} \mathrm{D}_{50}^{1.5}
$$

Bed sediment discharges that flow through the river cross section as follows.

$$
Q_{b}=q_{b} \cdot b .
$$

With $: \mathrm{b}=$ average river width

\section{Result and Analysis}

\subsection{Bed Sediment Laboratory Test}

\begin{tabular}{|c|c|c|c|c|}
\hline \multirow{2}{*}{ No.Filter } & \multicolumn{3}{|c|}{ Escaped percent } & \multirow{2}{*}{$\begin{array}{l}\text { Average } \\
\text { Passing } \\
\text { Percent }\end{array}$} \\
\hline & Sample 1 & Sample 2 & Sample 3 & \\
\hline 4.75 & 97.16 & 91.33 & 92.52 & 93.67 \\
\hline 2.36 & 96.39 & 89.19 & 91.37 & 92.32 \\
\hline 1.19 & 95.39 & 87.91 & 90.24 & 91.18 \\
\hline 0.59 & 93.14 & 85.43 & 88.15 & 88.90 \\
\hline 0.425 & 92.77 & 84.97 & 87.57 & 88.44 \\
\hline 0.27 & 74.53 & 75.58 & 77.40 & 75.83 \\
\hline 0.25 & 50.63 & 58.72 & 63.46 & 57.60 \\
\hline 0.14 & 18.61 & 19.62 & 30.79 & 23.01 \\
\hline 0.07 & 12.87 & 9.66 & 21.83 & 14.79 \\
\hline
\end{tabular}

The testing of sediment characteristics conducted the Soil Mechanics Laboratory to classify sediment type can be seen in Fig. 4. Sediment samples of this study obtained from the Jeneberang river. The result of a specific gravity test can be seen in Table 1. Meanwhile, the filtration analysis is shown in Table 2 .

Table 1. Specific Gravity of Samples

\begin{tabular}{|c|c|}
\hline Sample Code & Specific gravity \\
\hline Sample 1 & 2.70 \\
\hline Sample 2 & 2.67 \\
\hline Sample 3 & 2.74 \\
\hline Average & 2.70 \\
\hline
\end{tabular}

Based on Table 1 the specific gravity obtained, the sediments of Jeneberang river consist of silty sand.

Table 2. Filter Analysis Test Result
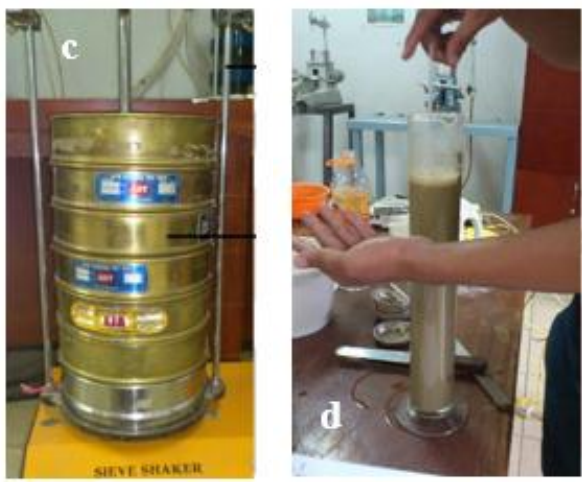

Figure 4. Sediment laboratory test: a) air-dried sediment, b) specific gravity test, c) sieve analysis, and d) hydrometer test 


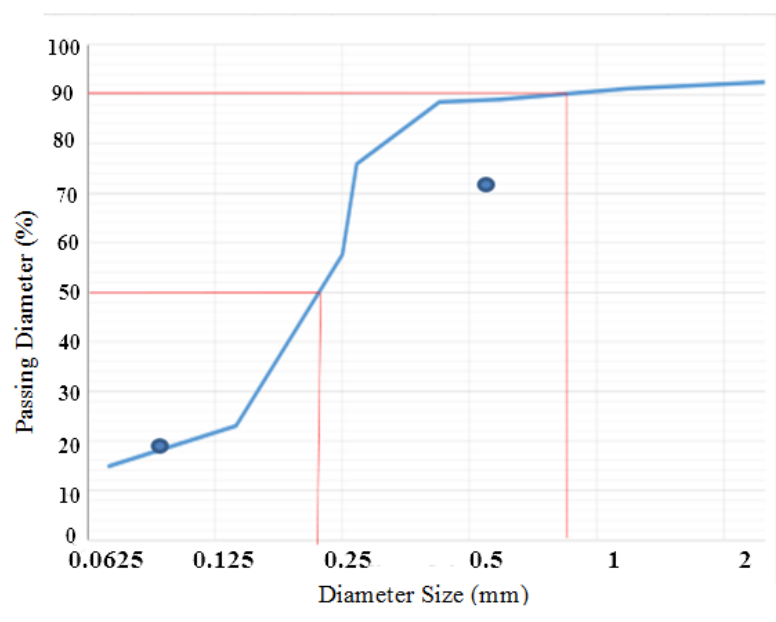

Figure 5. Relationship between passing material and diameter size
The sediment diameter determination through analysis experiment conducted in a laboratory to find grain diameter values $\mathrm{D}_{50}$ and $\mathrm{D}_{90}$; the value of $\mathrm{D}_{50}$ is $0.218 \mathrm{~mm}$ and $\mathrm{D}_{90}$ ) is $0.875 \mathrm{~mm}$, as seen in Fig. 5 .

\subsection{Flow Velocity}

Assuming the flow is uniform, the cross-section width knew from the measured result, further cross-section depth known as a calculated result in Table 3. Furthermore, the flow velocity calculated results, as represented in Table 4.

\subsection{Bed Sediment Discharge}

Bed sediment discharge calculated using Van Rijn formulation in Equation 1, 2, 3, and 4. Based on previous data analysis as in Table1-4 and Fig. 5, The flow rate and bed sediment discharge result analysis represented in Table 5 .

Table 3. Calculation of the Stream Depth by Trial And Error

\begin{tabular}{|c|c|c|c|c|c|c|c|c|}
\hline Q & $\mathrm{b}$ & d & A & $\mathrm{P}$ & $\mathrm{R}$ & $\mathrm{AR}^{2 / 3}$ & $\left(\mathrm{n}^{*} \mathrm{Q}\right) / \sqrt{ } \mathrm{s}$ & \multirow{2}{*}{ Correction } \\
\hline$\left(\mathrm{m}^{3} / \mathrm{s}\right)$ & (m) & (m) & $(m)^{2}$ & (m) & (m) & (m) & (m) & \\
\hline 547.01 & 126 & 1.843 & 232.22 & 129.7 & 1.791 & 342.424 & 342.523 & 0.099 \\
\hline 429.07 & 126 & 1.591 & 200.47 & 129.2 & 1.552 & 268.699 & 268.672 & 0.027 \\
\hline 334.37 & 126 & 1.368 & 172.37 & 128.7 & 1.339 & 209.392 & 209.377 & 0.016 \\
\hline 247.51 & 126 & 1.140 & 143.64 & 128.3 & 1.120 & 154.889 & 154.982 & 0.093 \\
\hline 122.15 & 126 & 0.745 & 93.87 & 127.5 & 0.736 & 76.541 & 76.489 & 0.052 \\
\hline 88.27 & 126 & 0.612 & 77.112 & 127.2 & 0.606 & 55.228 & 55.275 & 0.047 \\
\hline 61.02 & 126 & 0.491 & 61.866 & 127 & 0.487 & 38.305 & 38.207 & 0.098 \\
\hline 46.82 & 126 & 0.418 & 52.668 & 126.8 & 0.415 & 29.315 & 29.317 & 0.002 \\
\hline 11.72 & 126 & 0.182 & 22.932 & 126.4 & 0.181 & 7.351 & 7.336 & 0.015 \\
\hline
\end{tabular}

Table 4. Calculation of Average Flow Velocity

\begin{tabular}{|c|c|c|c|c|c|c|c|c|}
\hline $\mathrm{Q}$ & $\mathrm{d}(\mathrm{h})$ & $\mathrm{b}$ & $\mathrm{S}$ & $\mathrm{A}$ & $\mathrm{P}$ & $\mathrm{R}$ & $\mathrm{U}$ & $\mathrm{Qs}$ \\
\hline$\left(\mathrm{m}^{3} / \mathrm{s}\right)$ & $(\mathrm{m})$ & $(\mathrm{m})$ & & $(\mathrm{m})^{2}$ & $(\mathrm{~m})$ & $(\mathrm{m})$ & $(\mathrm{m} / \mathrm{s})$ & $\left(\mathrm{m}^{3} / \mathrm{s}\right)$ \\
\hline 547.01 & 1.843 & 129.375 & 0.003124 & 238.4381 & 133.061 & 1.792 & 2.356 & 561.775 \\
\hline 429.07 & 1.591 & 128.334 & 0.003124 & 204.1794 & 131.516 & 1.553 & 2.141 & 437.191 \\
\hline 334.37 & 1.368 & 127.515 & 0.003124 & 174.4405 & 130.251 & 1.339 & 1.940 & 338.476 \\
\hline 247.51 & 1.140 & 126.623 & 0.003124 & 144.3502 & 128.903 & 1.120 & 1.722 & 248.594 \\
\hline 122.15 & 0.745 & 125.571 & 0.003124 & 93.5504 & 127.061 & 0.736 & 1.302 & 121.816 \\
\hline 61.02 & 0.491 & 125.109 & 0.003124 & 61.4285 & 126.091 & 0.487 & 0.989 & 60.739 \\
\hline 46.82 & 0.418 & 124.977 & 0.003124 & 52.2404 & 125.813 & 0.415 & 0.889 & 46.433 \\
\hline 11.72 & 0.182 & 124.548 & 0.003124 & 22.6677 & 129.912 & 0.181 & 0.512 & 11.603 \\
\hline
\end{tabular}


Table 5. Calculation Results of Flow Rate $(\mathrm{Q})$ and Bed Sediment Discharge $\left(\mathrm{Q}_{\mathrm{B}}\right)$

\begin{tabular}{|c|c|c|c|c|c|c|c|c|c|c|c|c|c|c|}
\hline $\mathrm{Q}$ & $\mathrm{d}(\mathrm{h})$ & $\mathrm{b}$ & $\mathrm{U}$ & D50 & D 90 & $\mathrm{D}^{*}$ & $\mathrm{qcr}$ & $\mathrm{u}^{*} \mathrm{cr}$ & $\mathrm{C}^{\prime}$ & $\mathrm{U}^{*}$ & $\mathrm{~T}$ & $\varphi$ & \multicolumn{2}{|c|}{$\mathrm{Qb}$} \\
\hline$\left(\mathrm{m}^{3} / \mathrm{s}\right)$ & (m) & (m) & $(\mathrm{m} / \mathrm{s})$ & $(\mathrm{mm})$ & $(\mathrm{mm})$ & & $(\mathrm{m})^{2}$ & (m) & (m) & $(\mathrm{m} / \mathrm{s})$ & & & $\mathrm{Kg} / \mathrm{s}$ & $\left(\mathrm{m}^{3} / \mathrm{s}\right)$ \\
\hline 547.01 & 1.843 & 129.375 & 2.356 & 0.000218 & 0.000875 & 6.002 & 0.044 & 0.013 & 70.660 & 0.104 & 66.309 & 0.002725 & 953.241 & 83260.05 \\
\hline 429.07 & 1.591 & 128.334 & 2.141 & 0.000218 & 0.000875 & 6.002 & 0.044 & 0.013 & 69.511 & 0.096 & 56.447 & 0.001943 & 660.801 & 57093.21 \\
\hline 334.37 & 1.368 & 127.515 & 1.940 & 0.000218 & 0.000875 & 6.002 & 0.044 & 0.013 & 68.330 & 0.089 & 47.819 & 0.001372 & 463.454 & 40042.42 \\
\hline 247.51 & 1.140 & 126.623 & 1.722 & 0.000218 & 0.000875 & 6.002 & 0.044 & 0.013 & 66.905 & 0.081 & 39.113 & 0.000899 & 301.762 & 26072.23 \\
\hline 122.15 & 0.745 & 125.571 & 1.302 & 0.000218 & 0.000875 & 6.002 & 0.044 & 0.013 & 63.580 & 0.064 & 24.394 & 0.000334 & 111.040 & 9593.85 \\
\hline 61.02 & 0.491 & 125.109 & 0.989 & 0.000218 & 0.000875 & 6.002 & 0.044 & 0.013 & 60.320 & 0.051 & 15.267 & 0.000125 & 41.350 & 3572.63 \\
\hline 46.82 & 0.418 & 124.977 & 0.889 & 0.000218 & 0.000875 & 6.002 & 0.044 & 0.013 & 59.062 & 0.047 & 12.711 & 0.000085 & 28.114 & 2429.09 \\
\hline 11.72 & 0.182 & 124.548 & 0.512 & 0.000218 & 0.000875 & 6.002 & 0.044 & 0.013 & 52.562 & 0.031 & 4.742 & 0.000011 & 3.533 & 305.23 \\
\hline
\end{tabular}


Furthermore, calculation results plotted on logarithmic paper in Fig. 6, and a combined sedimentary curve was obtained for all daily discharge samples, and bed sediment equation (bad load) was obtained $\mathrm{X}=\mathrm{Q}$ and coefficient $\mathrm{Y}=$ $\mathrm{Qb} . \mathrm{R}^{2}=$ correlation curve sediment observations for several sediment samples. Figure 6 shows the relationship between bed sediment discharge $(\mathrm{Qb})$ and flow rate $(\mathrm{Q})$ determined as in Equation 5.

$$
\mathrm{Q}_{\mathrm{b}}=12,314 \times \mathrm{Q}^{1,4294}
$$

Where: $\mathrm{Q}_{\mathrm{b}}=$ base sediment discharge (ton/day), and $\mathrm{Q}=$ flow rate $\left(\mathrm{m}^{3} / \mathrm{sec}\right)$.

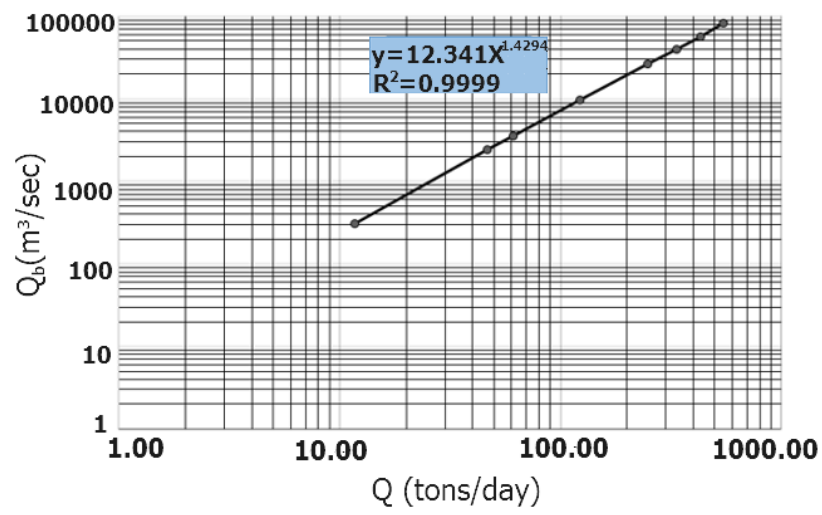

Figure 6. The relationship between flow rate $(\mathrm{Q})$ and bed sediment discharge $\left(\mathrm{Q}_{\mathrm{b}}\right)$

Based on Equation 5, the daily bed sediment discharge known, further the calculation results represented in Table 6.

Table 6. Calculation Results of Bed Sediment Discharge (Qb) Daily

\begin{tabular}{|c|c|c|c|c|}
\hline Year & Month & Date & $\mathrm{Q}(\mathrm{m} 3 / \mathrm{s})$ & $\mathrm{Qb}$ (tonnes/ day) \\
\hline \multirow{5}{*}{2014} & \multirow{5}{*}{ January } & 1 & 194.92 & 23146.4 \\
\hline & & 2 & 123.01 & 11987.5 \\
\hline & & 3 & 63.22 & 4628.8 \\
\hline & & 4 & 85.89 & 7173.9 \\
\hline & & 5 & 42.20 & 2597.6 \\
\hline & & . & . & . \\
\hline & & . & . & . \\
\hline \multirow{4}{*}{2018} & \multirow{4}{*}{ December } & 28 & 25.30 & 1250.22 \\
\hline & & 29 & 25.31 & 1251.16 \\
\hline & & 30 & 27.23 & 1388.68 \\
\hline & & 31 & 27.44 & 1404.11 \\
\hline
\end{tabular}

Based on the results of laboratory tests for sediment grain size and analysis that has been carried out, it is known that Bilibili sediment is dominated by silt and fine sand. This result is the following research conducted by Maddi et al. [25] and Lukman et al. [26]. In some areas in eastern Indonesia, the average sediment transport is dominated by fine silt-sand. The research conducted by Nugroho and Basit [32] and Crabbe and Smith in Wakatobi Island, Indonesia [33]. Therefore, based on the results of sediment analysis using bedload to obtain the amount of sediment currently present in the Bilibili dam, this study strongly supports several previous studies that have been carried out at the location by Maddi et al. [25], and Lukman et al. [26]. Besides, this research by the results agreed with a study conducted by Otun and Adeogun [34] on Kubbani Reservoir, Zaria, Nigeria, and concluded that the control of sedimentation in Kubanni Reservoir requires a radical approach than ever before. Furthermore, the equation obtained for the relationship between sediment discharge and flow rate can quickly determine the amount of sediment in the future. The study results greatly help the dam manager decide the number of deposits so that it can be easier to anticipate in the worst conditions, for example, in the rainy season. High rainfall intensity causes high eroded sediment flow from the headwaters and affects the amount of sedimentation. Therefore, this study's results can be used as a guide for managers in preparing future dam management plans.

\section{Conclusions}

Transport sediment analysis using bed-load conducted and found the relationship between bed sediment discharge and flow rate expressed in equation $y=12.314 \mathrm{x}^{1.4292}$ where $\mathrm{y}=\mathrm{x} \cdot \mathrm{Qb}=\mathrm{Q}$. Therefore, the existing sediment transport amount of the Bilibili reservoir for 2014 to 2018 is 1.102 million tons, 1.426 million tons, 0.737 million tons, 1.277 million tons, and 0.895 million tons, respectively.

The previous study results conducted by Wahana Krida Konsulindo found total sediment volume was 5.437 million $\mathrm{m}^{3}$ while the present study found 216,9261.2 tons/year equivalent to $6,142 \mathrm{~m}^{3} /$ year. Moreover, the percentage of bed sediment transport to total sediment is $70.5 \%$.

The analysis results also indicate that the increase in bed sediment discharge is due to an increase in river water discharge. The condition explains that increasing the flow rate can cause the amount of transported sediment to increase.

\section{Acknowledgments}

We would like to thanks and appreciated all who have helped in this study and completed this paper. We also appreciated those who have reviewed this paper to make it better and more useful. 


\section{REFERENCES}

[1] G. M. Kondolf et al., "Sustainable sediment management in reservoirs and regulated rivers: Experiences from five continents," Earth's Futur., vol. 2, no. 5, pp. 256-280, 2014.

[2] E. B. Barbier, "Upstream dams and downstream water allocation: The case of the Hadejia-Jama'are floodplain, northern Nigeria," Water Resour. Res., vol. 39, no. 11, 2003.

[3] P. Angelidis, M. Kotsikas, and N. Kotsovinos, "Management of Upstream Dams and Flood Protection of the Transboundary River Evros/Maritza," Water Resour. Manag., vol. 24, no. 11, pp. 2467-2484, 2010.

[4] A. Said, "The implementation of a Bayesian network for watershed management decisions," Water Resour. Manag., vol. 20, no. 4, pp. 591-605, 2006.

[5] M. Acreman, "Managed Flood Releases from Reservoirs: Issues and Guidance Prepared for Thematic Review II.1: Dams, ecosystem functions and environmental restoration Go Back," 2000.

[6] P. Sw and S. T. Stockholm, "Jeneberang River Basin," Science (80-. )., 2005.

[7] D. Rickenmann, "Bed-load transport measurements with geophones and other passive acoustic methods," J. Hydraul. Eng., vol. 143, no. 6, 2017.

[8] D. Rickenmann et al., "Bedload transport measurements with impact plate geophones: Comparison of sensor calibration in different gravel-bed streams," Earth Surf. Process. Landforms, vol. 39, no. 7, pp. 928-942, 2014.

[9] D. Rickenmann, J. M. Turowski, B. Fritschi, A. Klaiber, and A. Ludwig, "Bedload transport measurements at the Erlenbach stream with geophones and automated basket samplers," Earth Surf. Process. Landforms, vol. 37, no. 9, pp. 1000-1011, 2012.

[10] D. Abraham, R. A. Kuhnle, and A. J. Odgaard, "Validation of bed-load transport measurements with time-sequenced bathymetric data," J. Hydraul. Eng., vol. 137, no. 7, pp. 723728, 2011.

[11] J. S. Ribberink, "Bed-load transport for steady flows and unsteady oscillatory flows," Coast. Eng., vol. 34, no. 1-2, pp. 59-82, 1998.

[12] L. C. van Rijn, "Unified view of sediment transport by currents and waves. III: Graded beds," J. Hydraul. Eng., vol. 133, no. 7, p. 761, 2007.

[13]F. Meyer, "Topographic distance and watershed lines," Signal Processing, vol. 38, no. 113-125, 1994.

[14] J. E. Flotemersch, S. G. Leibowitz, R. A. Hill, J. L. Stoddard, M. C. Thoms, and R. E. Tharme, "A watershed integrity definition and assessment approach to support strategic management of watersheds," River Res. Appl., vol. 32, no. 1654-1671, 2016.

[15] W. James, Simulation Modeling in Watershed management. New York, United States: Springer Verlag, 2001.

[16] I. w. Heatchote, Integrated Watershed Management: Princiles and Practice, 2nd ed. New Jersey: Jhon Wiley and Sons, 209AD.
[17] K. W. Pilarczyk and S. N. Nguyen, "Experience and practices on flood control in Vietnam," Water Int., vol. 30, no. 1, pp. 114-122, 2005.

[18] M. Newson, Land, water and development: sustainable and adaptive management of rivers, 3rd ed. London and New York: Routledge, 2008.

[19] M. A. Allison and E. A. Meselhe, "The use of large water and sediment diversions in the lower Mississippi River (Louisiana) for coastal restoration," J. Hydrol., vol. 387, no. 3-4, pp. 346-360, 2010.

[20] R. G. Darmody, J. C. Marlin, J. Talbott, R. A. Green, E. F. Brewer, and C. Stohr, "Dredged Illinois River Sediments," $J$. Environ. Qual., vol. 33, no. 2, pp. 458-464, 2004.

[21]J. A. Gore and J. Banning, Discharge Measurements and Streamflow Analysis, vol. 1. Elsevier Inc., 2017.

[22] H. McMillan, J. Freer, F. Pappenberger, T. Krueger, and M. Clark, "Impacts of uncertain river flow data on rainfall-runoff model calibration and discharge predictions," Hydrol. Process., vol. 24, no. 10, pp. 1270-1284, 2010.

[23] J. D. Milliman, K. L. Farnsworth, P. D. Jones, K. H. Xu, and L. C. Smith, "Climatic and anthropogenic factors affecting river discharge to the global ocean, 1951-2000," Glob. Planet. Change, vol. 62, no. 3-4, pp. 187-194, 2008.

[24] J. Greensmith, Petrology of the sedimentary rocks. Springer Science \& Business Media, 2012.

[25] H. C. Maddi, M. S. Pallu, M. A. Thaha, and R. Lopa, "Counter measures Energy on Debris Flow Event by Open-Type Sabo Dam Model," Int. J. Appl. Eng. Res., vol. 13, no. 3, pp. 1694-1702, 2018.

[26] M. Lukman, B. Tanan, and Z. Saing, "Sediment yields determination of existing bilibili reservoir using echosounder data analysis," Int. J. Adv. Sci. Technol., vol. 29, no. 5, pp. 3652-3659, 2020.

[27] S. Deni, J. Rasai, and Z. Saing, "Public policy analysis on disaster threat due to geo-environmental condition of Tugurara River in Ternate City, North Maluku Province," Int. J. GEOMATE, vol. 17, no. 60, pp. 211-218, 2019.

[28] P. Wilcock, J. Pitlick, and Y. Cui, "Estimating Bed-Material Transport in Gravel-bed Rivers," Geography, vol. RMRS-GTR-2, no. May, pp. 1-5, 2009.

[29] A. Amiri-Simkooei, M. Snellen, and D. G. Simons, "Riverbed sediment classification using multi-beam echo-sounder backscatter data," J. Acoust. Soc. Am., vol. 126, no. 4, p. 1724, 2009.

[30] M. Church, "Bed Material Transport and the Morphology of Alluvial River Channels," Annu. Rev. Earth Planet. Sci., vol. 34, no. 1, pp. 325-354, 2006.

[31]V. R. Leo C., "Sediment Transport, Part: Bed Load Transport," J. Hydraul. Eng., vol. 110, pp. 1431-1456, 1984.

[32] S. H. Nugroho, A. Basit, "Sediment Distribution Based on Grain Size Analyses in Weda Bay, Northern Maluku," Jurnal Ilmu dan Teknologi KelautanTropis, vol. 6, no. 1, p. 229-240, 2014.

[33] M.C.J. Crabbe, D.J. Smith, "Sediment Impacts on Growth 
Rates of Acropora and Porites Corals from Fringing Reefs of Sulawesi, Indonesia. Coral Reefs," vol. 24, p. 437-441, 2005.
[34] Otun J.A., and Adeogun B.K, “Analysis of Fluvial Sediment Discharges into Kubanni Reservoir," Nigerian Journal of Technology, vol. 29 no 2, p. 64-75, 2010. 